\title{
Anticonvulsant, Anxiolytic and Sedative Activities Of The Methanol Extract of Abrus Precatorius (Linn.) Leaves
}

\author{
Jacob Olayemi ${ }^{\mathrm{a}}$, Adewale Bakre ${ }^{\mathrm{b}^{\star}}$, Esther Oshirekua ${ }^{\mathrm{a}}$, Segun Olowoparija ${ }^{\mathrm{b}, \mathrm{c}}$ \\ a Department of Pharmacognosy, Faculty of Pharmacy, University of Ibadan, Nigeria \\ b Department of Pharmacology and Therapeutics, College of Medicine, University of Ibadan, Nigeria \\ c Department of Pharmacology and Therapeutics, Faculty of Basic Clinical Science, University of Medical Sciences, Ondo, \\ Nigeria
}

\begin{abstract}
Abrus precatorius $L$. is a woody twinning climber, a member of the Fabaceae family indigenous to parts of Asia and Africa. It has been used widely in traditional medicine for curing many conditions such as malaria, sores, chest pain, cough, inflammation and many others. It was also reported that the hot water extract of the leaves and the roots have been used in treating persons suffering from episodes of convulsions in Tanzania. The aim of this present study was to evaluate the anti-convulsant, anxiolytic and sedative activities of the methanol extract of $A$. precatorius (Linn.) leaves in-vivo using murine models of convulsion, anxiety and sedation.

The anticonvulsant activity of ethanol extract of $A$. precatorius leaves was investigated using pentylene tetrazole, strychnine and picotoxin-induced convulsion. Anxiety tests used included head dips and elevated plus maze. Phenobarbitone-induced sleeping test was used to assess the sedative effect of $A$. precatorius. Safety of the extract was determined using the brine shrimp lethality assay.

Preliminary phytochemical screening on the dried and powdered leaves indicated that alkaloids, tannins, flavonoids and saponins, with a yield of $17.40 \%$ are present in the leaves. The brine shrimp lethality assay showed a $\mathrm{LC}_{50}$ of $8.189 \mu \mathrm{g} / \mathrm{ml}$.Results from the in-vivo neuropharmacological profile of the crude methanol extract of the leaves at doses of 200,400 and $800 \mathrm{mg} / \mathrm{kg}$ body weight had central effects although not sig-

Corresponding author:

Adewale G. Bakre,

Department of Pharmacology \& Therapeutics, College of Medicine, University of Ibadan, Ibadan, Nigeria.

Telephone: +2348081062365

E-mail: bakreeyitemi@live.com

ORCID

Jacob Olayemi 0000-0002-5504-7960,

Adewale Bakre 0000-0001-9769-8510,

Esther Oshireku 0000-0001-6276-6077,

Segun Olowoparija 0000-0003-3232-1901

(Received 25 January 2020, accepted 30 April 2020)
\end{abstract}


nificant ones compared with diazepam which was used as the standard. The results from the convulsion studies expressed as percentage protection indicates that 400mg/ $\mathrm{kg}$ and $800 \mathrm{mg} / \mathrm{kg}$ had $25 \%$ protection against pentylenetetrazol induced convulsions. The methanol extract of $A$. precatorius leaves might possess anticonvulsant and sedative activities, thus justifying its use in the management of epilepsy.

Keywords: Anticonvulsant, Anxiolytic, sedative, Abrus precatorius, epilepsy.

\section{INTRODUCTION}

Abrus precatorius $L$. is a woody twinning climber, a member of the Fabaceae family indigenous to parts of Asia and Africa. It has been used widely in traditional medicine for curing many conditions such as malaria, sores, chest pain, cough, inflammation and many others. It was also reported that the hot water extract of the leaves and the roots have been used in treating persons suffering from episodes of convulsions in Tanzania.

Over 50 million people are estimated to have epilepsy, making it one of the most common non-communicable neurological diseases, with a very large proportion of affected persons living in developing countries of the world, especially in Asia and Africa. A vast majority of these patients rely on traditional medicine almost exclusively because therapy is symptomatic, controlling seizures in only about $25 \%$, and neither effective prophylaxis nor cure is available ${ }^{1}$. The characteristics of the disease are periodic and unpredictable seizures due to disordered, synchronous and rhythmic firing of population of the brain's neurons ${ }^{2}$. A study in south western Nigeria identified the cause of epilepsy as psychological stress, head injury, birth or head injury, and supernatural or due to a contagion ${ }^{3}$.

Over the years, various mechanisms to alleviate the condition have led to the development/production of a wide variety of antiepileptic drugs (AEDs). AEDs are classified majorly into first, second and third generations, with 14 new AEDs licensed for clinical use between 1989 and 2009. Majority of the AEDs have very potent adverse effects and drug interactions, but the third-generation drugs exhibit less interaction compared with the first- and second-generation AEDs ${ }^{4}$. The ideal AED would suppress all seizures without causing any unwanted effects. Unfortunately, none of the current drugs used control seizure activity without frequent unwanted effects which include impairment of the CNS, drowsiness, lethargy, euphoria, dizziness, headache, and convulsion. Anxiety is a common psychological disorder in epileptics ${ }^{5}$. It is described as an unpleasant emotional state with an unidentified, uncontrollable and unavoidable cause.

The hot water extract of the leaves of Abrus precatorius (Linn.) is used in traditional medicine of various neurological conditions including convulsion ${ }^{6}$. How- 
ever, there is paucity of detailed scientific study of Abrus precatorius leaf extract applied on the central nervous system to control convulsions. The aim of this present study was to evaluate the anti-convulsant anxiolytic and sedative activities of the methanol extract of $A$. precatorius (Linn.) leaves in-vivo using murine models of convulsion, anxiety and sedation.

\section{METHODOLOGY}

\section{Plant material and preparation of extract}

The plant material was collected in May 2016 from the University of Ibadan Botanical Gardens. It was identified and authenticated at the Forest Herbarium Ibadan, Oyo State, Nigeria in the Forestry Research Institute of Nigeria, Ibadan, where a voucher specimen (FHI. 110694.) was obtained and deposited. The leaves of flowering A. precatorius were dried properly in air and then pulverized using a blender to obtain a coarsely ground powder which was extracted using cold extraction method with distilled methanol. $178 \mathrm{~g}$ of the coarse powder was macerated in a macerating tank for 48 hours exhaustively. The crude extract was decanted off and filtered. It was thereafter concentrated at $20^{\circ} \mathrm{C}$ using the rotary evaporator (BUCHI Rota vapor R-205).

\section{Animal}

Young male albino Swiss mice (18-25 g) were obtained from the Animal Centre, College of Medicine, University of Ibadan, Nigeria, and were housed in plastic cages at room temperature with a 12:12 h light-dark cycle. They were fed with balanced rodent pellet diet and water ad libitum. The animals were acclimatized for at least 1 week before being used for experiments. The experimental procedures were following the National Institutes of Health Guide for Care and Use of Laboratory Animals (Publication No. 85-23, revised 1985).

\section{Drugs and chemicals}

Diazepam (Hoffman-La Roche, Switzerland), pentylenetetrazol (Sigma, USA), picrotoxin (Sigma, USA), and strychnine (Shaanxi Xin Sheng Long Industrial Co., Ltd. China).

\section{Experimental design}

Thirty mice randomly divided into six groups $(n=5)$ were used for all the tests except the anticonvulsant assays. The groups included two controls (vehicle and standard drug) and four treatment groups for doses 100, 200, 400 and $800 \mathrm{mg} /$ $\mathrm{Kg}$. A similar grouping was used for the anticonvulsant test except that there were 10 animals per group $(\mathrm{n}=10)$ 


\section{Brine shrimp lethality assay}

The stock solution of the crude methanol extract of $A$. precatorius with concentration of $1000 \mu \mathrm{g} / \mathrm{ml}$ was prepared by dissolving $50 \mathrm{mg}$ of the extract in $5 \mathrm{ml}$ of natural sea water. Concentrations of $1000 \mu \mathrm{g} / \mathrm{ml}, 500 \mu \mathrm{g} / \mathrm{ml}, 100 \mu \mathrm{g} / \mathrm{ml}$, $10 \mu \mathrm{g} / \mathrm{ml}$ and $1 \mu \mathrm{g} / \mathrm{ml}$ were used for the assay by appropriate dilution with sea water in sample bottles. The experiment was carried out in triplicates. Ten viable Artemia salina were introduced into each sample bottle and made up to $5 \mathrm{ml}$ using natural sea water. After a period of 24 hours, the number of dead shrimps was counted and recorded 7 .

\section{Novelty induced behavior (NIB)}

NIB was assessed using the method described by Ajayi and Ukponmwan (1994) ${ }^{8}$ with some modifications. The mice were allowed 6-10 mins epochs during which locomotion, rearing and grooming were observed and scored to allow for characterization of drug-induced alterations. The mice were then returned to their home cages. Each test session involved allowing the mice to acclimatize to the testing environment (a quiet well-ventilated room) for 30 mins. All behavioral testing was carried out between 9 am and $2 \mathrm{pm}$. Six groups of five mice each were given $10 \mathrm{~mL} / \mathrm{Kg}$ vehicle; $100,200,400$ and $800 \mathrm{mg} / \mathrm{Kg}$ MEAP; and $3 \mathrm{mg} / \mathrm{kg}$ diazepam orally, before placement in the open field arena. The open field is a rectangular arena composed of a hardboard floor $\left(36 \times 36 \mathrm{~cm}^{2}\right)$ with a surrounding wall (30 $\mathrm{cm}$ high) made of white painted wood. The extract dosages were chosen guided by brine shrimp lethality assay and literature. (Similar doses were used in other protocols in this study.)

The floor was divided into squares of $9 \mathrm{~cm}^{2}$. One hour after administration, each mouse was introduced into the arena; the frequency of grooming (the number of body cleaning with paws picking of the body and pubis with mouth and face washing actions) and rearing frequency (number of times each mouse stands on its hind legs or with its forearms against the wall of the cage or in free air) were scored for 30 mins. The procedure was repeated for all the mice in the different groups. After each session, the floor of the apparatus was wiped with $70 \%$ ethanol and dried thoroughly to remove traces of previous path.

\section{Exploratory activity}

To determine potential sedative effects, the hole-board test was used. The holeboard is a wooden board $\left(40 \times 40 \mathrm{~cm}^{2}\right)$ with 16 holes (diameter $3 \mathrm{~cm}$ ) evenly spaced on the floor ${ }^{9}$. Immediately after the NIB test for each mouse, it was placed at the center of the hole-board and the number of head dips into the holes was scored over a 5 mins period. Results obtained were expressed as mean total number 
of head dips (Lister, 1987). The procedure was repeated for all the mice in the different groups. After each trial, the floor of the apparatus was wiped with $70 \%$ ethanol and dried thoroughly to remove traces of previous path.

\section{Learning and memory}

Y-maze was used to assess the effect of the extract on short term memory. The Y-maze is composed of three equally spaced arms $\left(120^{\circ} ; 41 \times 15 \times 5 \mathrm{~cm}\right)$. The parameters assessed were arm entries (locomotor activity) and spontaneous alternation performance (memory). Immediately after the hole-board test for each mouse, it was placed in one of the arm compartments and allowed to move freely for 5 mins. Entry was defined as when the body (excepting the tail) of a mouse completely enters into an arm compartment. The sequence of entry was manually recorded. Alternation is defined as entry into all three arms consecutively. The arms were labeled $\mathrm{A}, \mathrm{B}$, and $\mathrm{C}$, and consecutive entries $\mathrm{ABC}, \mathrm{BCA}$, and $\mathrm{CAB}$. The maximum number of spontaneous alternations was then calculated as:

[Total number of arms entered]- 2;

Percentage alternations was calculated as

$\left[\frac{\text { Actual alternation }}{\text { Maximum alternation }}\right]$ (X100) (10)

The procedure was repeated for all the mice in the different groups. The apparatus was cleaned after each session to eliminate the odor left off the immediately preceding mouse $\mathrm{e}^{11}$.

\section{Anxiolytic test}

The elevated plus maze model ${ }^{12,{ }^{13}}$ was used to assess anti-anxiety effect. Lister (1987) ${ }^{14}$ validated the use of the elevated plus maze in testing anxiolytic effect in mice. First, the mice were assessed for the aversion of the open space and height. For this aspect, the elevated plus maze with two open and two closed arms was used. The plus maze used is made of wood with open arms $(30 \times 5 \times 15 \mathrm{~cm})$ and closed arms $(30 \times 5 \times 15 \mathrm{~cm})$. The arms extend from the central platform $(5 \times 5 \mathrm{~cm})$. The open arms, the central platform, and the floor of the closed arms were painted black. Next, the apparatus was mounted on a wooden base at an elevation of 38.5 $\mathrm{cm}$ above floor level. For the open arms, a slight ledge $4 \mathrm{~mm}$ high was erected to prevent the mice from slipping and falling off the edge. Immediately after the learning and memory test, each mouse was placed one after another at the center facing one of the closed arms and assessed for 5 mins. The following behavior was scored: open arm entries, closed arm entries, time spent in open arm and time spent in closed arm. The procedure was repeated for all the mice in the different 
groups except the group that was given diazepam; the group was replaced with another set of mice that was given $1 \mathrm{mg} / \mathrm{Kg}$ diazepam. After the assessment of each mouse, the lingering olfactory cues were cleansed using $70 \%$ ethyl alcohol. The doses used fell in the range that did not affect motor coordination ${ }^{15}$.

\section{Activity cage}

The locomotor activity of the mice was measured as horizontal and vertical movement using the multiple activity cage apparatus (Ugo Basile 47420) complete with two sets of emitter/sensor arrays for horizontal and vertical activity. A total of six rodents per group was placed in pairs of 2 mice per session in the activity cage for aduration of 5 minutes. The apparatus was preset for 2 mice per session of 5 minutes on two trials according to the manufacturer's manual. Thereafter, the rodents were returned to their home cages.

\section{Anticonvulsant tests}

Pentylenetetrazol-induced convulsion: PTZ ( $85 \mathrm{mg} / \mathrm{kg}$; s.c.) was used to induce clonic-tonic convulsion in mice ${ }^{16}$. The mice were divided into six groups of ten rodents each. The groups were $10 \mathrm{~mL} / \mathrm{Kg}$ vehicle; $100,200,400$ and $800 \mathrm{mg} / \mathrm{Kg}$ extract; and $40 \mathrm{mg} / \mathrm{Kg}$ phenobarbitone. One hour after the administration (p.o.), the convulsant was used to challenge the animals. The percentage of survival was recorded for each group.

Picrotoxin-induced convulsion: Picrotoxin (14 mg/kg; i.p.) ${ }^{17}$ was used to induce limbic seizures followed by status epilepticus in mice. Again, the mice were placed in six groups of ten rodents each. The groups were $10 \mathrm{~mL} / \mathrm{Kg}$ vehicle; 100,200 , 400 and $800 \mathrm{mg} / \mathrm{Kg}$ extract; and $40 \mathrm{mg} / \mathrm{Kg}$ phenobarbitone. Sixty minutes after initial administration (p.o.) the rodents were challenged using the convulsant. The survival percentage for each group was then recorded.

Strychnine-induced convulsion: seizures were induced using Strychnine (2 mg/ $\mathrm{kg}$; i.p.) ${ }^{17}$. Once more, every mouse was placed in a group of six with ten rodents each. Group onewas 10mL/Kg vehicle; groups two to five got 100, 200, 400 and $800 \mathrm{mg} / \mathrm{Kg}$ extract; while group six received $40 \mathrm{mg} / \mathrm{Kg}$ phenobarbitone. An hour from administration (p.o.) the convulsant was used to induce the rodents. Finally, the survival rate was recorded for each group.

\section{Statistical analysis}

Results of the experiments and observations were expressed as mean \pm standard error of mean (SEM). The significance of differences between groups was determined using one-way analysis of variance (ANOVA) followed by at least one of the following posthoc test: Dunnet's multiple comparison tests, Tukey's 
t-test and Student Neuman Keuls test. A level of significance $p<0.05$ or 0.01 was considered for each test.

\section{RESULTS AND DISCUSSION}

Secondary metabolites are the most beneficial active principles derived from various parts of plants and over time, scientific evidence that they possess the pharmacological activities for which the plant is known are being provided. The therapeutic or prophylactic effects of plant materials typically result through additive or synergistic action of the secondary metabolites present in the plant acting at single or multiple target sites associated with a physiological process $^{18}$. The combination of secondary metabolites in a particular plant is often taxonomically distinct ${ }^{19}$. This could be the basis for the specificity and uniqueness of medicinal actions of plant. Preliminary phytochemical screenings of the crude methanol extract of the leaves of $A$. precatorius (MEAP) show the presence of alkaloids, tannins, saponins and flavonoids which are responsible for the various pharmacological actions of the leaves and extracts from the leaves of the plant. Alkaloids e.g. piperine, raubasine have been shown specifically to possess anticonvulsant activities as well as flavonoids, terpenoids and saponins. Adedapo et al., ${ }^{20}$ reported that intraperitoneal $\mathrm{LD}_{50}$ of $A$. precartoris in ethanol in mice is less than $0.1 \mu \mathrm{g} / \mathrm{kg}$, while Ogbuehi et al., $2015^{21}$ gave oral $\mathrm{LD}_{50}$ in methanol to be $3942 \mathrm{mg} / \mathrm{kg}$. The study revealed that the extract might be cytotoxic with $\mathrm{LC}_{50}$ of $8.189 \mu \mathrm{g} / \mathrm{ml}$. Compounds or extract with $\mathrm{LC}_{50}$ value less than $1000 \mu \mathrm{g} / \mathrm{ml}$ are considered to be cytotoxic while those giving $\mathrm{LC}_{50}$ values greater than $1000 \mu \mathrm{g} /$ $\mathrm{ml}$ are not considered to $\mathrm{be}^{22}$.

Table 1: Table of results from Brine shrimp lethality assay.

\begin{tabular}{cccccc}
\hline $\begin{array}{c}\text { Concentrations } \\
(\boldsymbol{\mu g} / \mathrm{ml})\end{array}$ & $\begin{array}{c}\text { Death in } 1^{\text {st }} \\
\text { vial }(\mathbf{x} / \mathbf{1 0})\end{array}$ & $\begin{array}{c}\text { Death in } 2^{\text {nd }} \\
\text { vial }(\mathbf{x} / \mathbf{1 0})\end{array}$ & $\begin{array}{c}\text { Death in } 3^{\text {rd }} \\
\text { vial }(\mathbf{x} / \mathbf{1 0})\end{array}$ & $\begin{array}{c}\text { Total death } \\
(\mathbf{x} / \mathbf{3 0})\end{array}$ & $\%$ mortality \\
\hline $\mathbf{1 0 0 0}$ & 9 & 10 & 10 & 29 & 96.7 \\
\hline $\mathbf{5 0 0}$ & 9 & 7 & 10 & 26 & 86.7 \\
\hline $\mathbf{1 0 0}$ & 6 & 3 & 9 & 18 & 60 \\
\hline $\mathbf{1 0}$ & 6 & 4 & 3 & 13 & 43.3 \\
\hline $\mathbf{1}$ & 4 & 2 & 6 & 12 & 40 \\
\hline
\end{tabular}


Different pharmacological techniques were used to investigate the anxiolytic, anticonvulsant, and sedative effects of MEAP. In activity cage, open field and hole board tests, decreased number of horizontal and vertical movements, rearing and grooming, and head dips respectively reveal that MEAP might possess sedative effect. Increased activities (movements, novelty induced behavior and head dips) of rodents are indicative of their explorative capability, which are also considered to be central excitatory behavior ${ }^{8}$. The reduction of these activities by MEAP could be due to their central inhibitory action on excitatory neural systems such as glutamatergic and dopaminergic systems among others or their possible potentiation of the central inhibitory systems such as $\gamma$-aminobutyric acid (GABA).

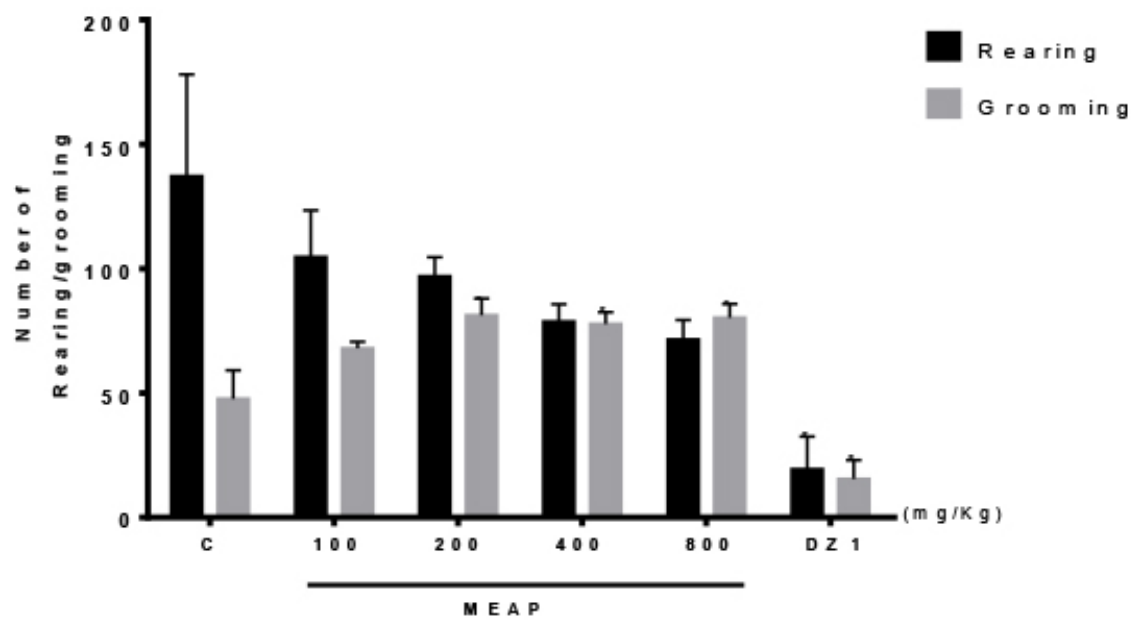

Figure 1: Effects of the methanol extract of the leaves of $A$. precatorius on Novelty-induced rearing and grooming in mice. Bars represent mean values with error bars. One-way ANOVA followed by Dunnet's multiple comparison test. * $p<0.05$, indicate significant difference from the control (distilled water). 


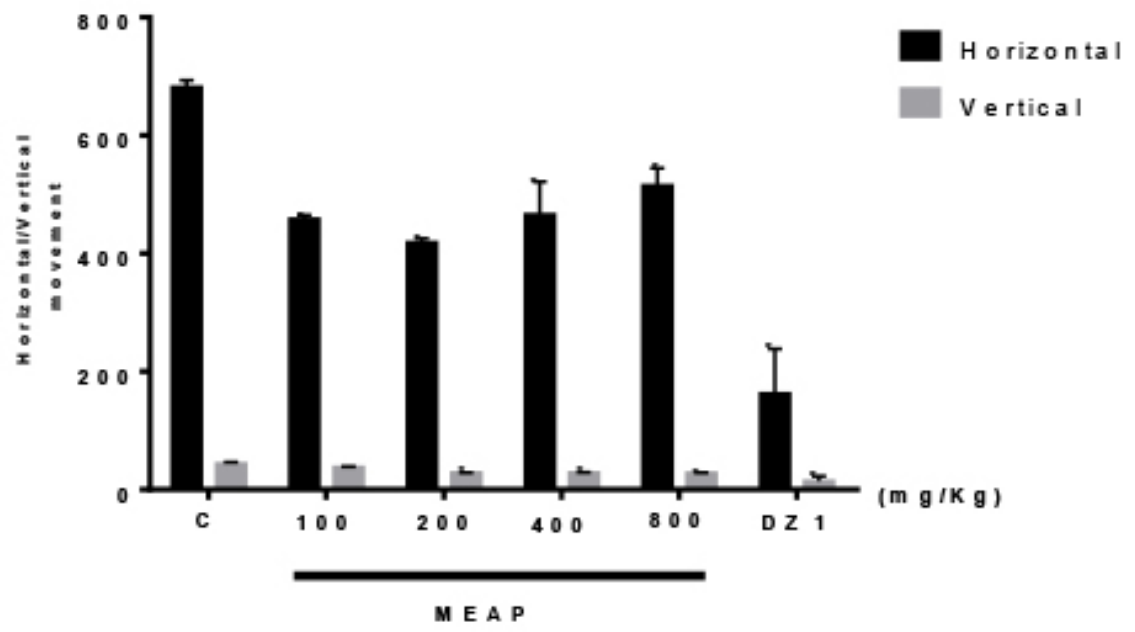

Figure 2: Effects of the methanol extract of the leaves of $A$. precatorius on horizontal and vertical locomotion in mice. Bars represent mean values with error bars. One-way ANOVA followed by Dunnet's multiple comparison test. * $p<0.05$, indicate significant difference from the control (distilled water).

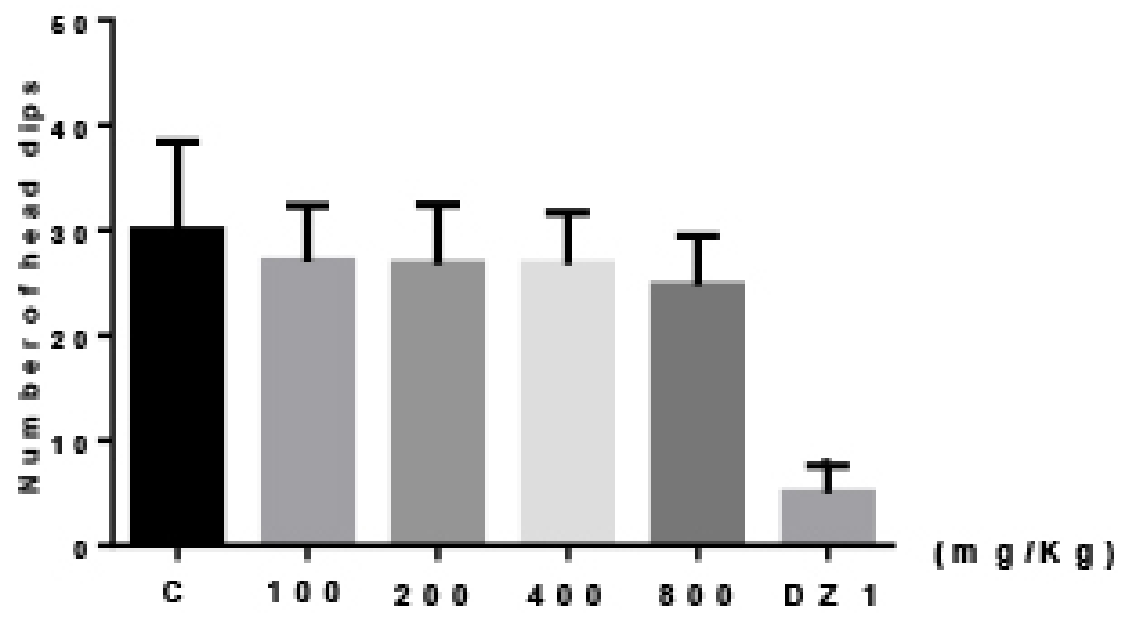

\section{E A P}

Figure 7: Effects of the methanol extract of $A$. precatorius leaves on exploratory behavior in mice Bars represent mean values with error bars. One-way ANOVA followed by Dunnet's multiple comparison test. * $p<0.05$, indicate significant difference from the control (distilled water). 
Also, the results from spontaneous alternation test using the Y-Maze showed that MEAP has no significant effect on spatial working memory at doses used in this study.

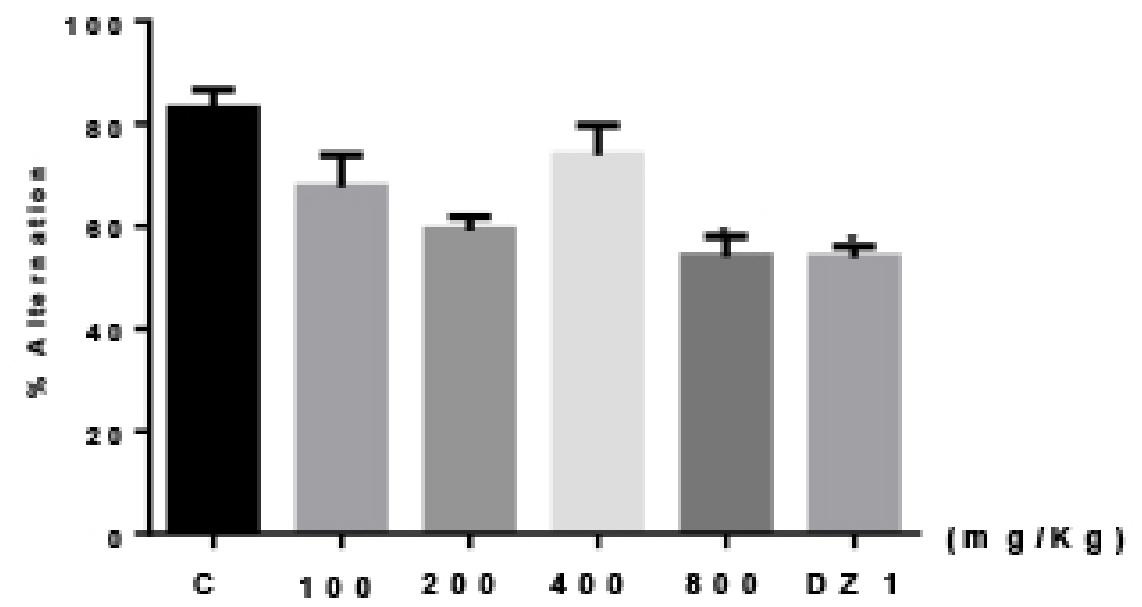

M E A P

Figure 3: Effects of the methanol extract of the leaves of Abrus precatorius on the percentage alternation of mice in the Y-maze.Bars represent mean values with error bars. One-way ANOVA followed by Dunnet's multiple comparison test. * $p<0.05$, indicate significant difference from the control (distilled water).

EPM favorable for testing of GABA $_{A}$-receptors linked anxiolytic drugs ${ }^{29,}{ }^{30}$. Agents, which increase animals' time spent and number of entries into open arms and/or reduce time spent and number of entries in closed arms of EPM, are considered to possess anxiolytic effects ${ }^{31}$. MEAP significantly decreased time spent in open arms (Figure 4), and increased time spent in closed arms (Figure 5) suggesting that it lacks anxiolytic activity. Avoidance of the open arm portrays a manifestation of fear and anxiety. MEAP increased the index of open arm avoidance (Figure 6). Standard benzodiazepine anxiolytic like diazepam increased time spent in open arm and reduced time in closed arm at $1 \mathrm{mg} / \mathrm{kg}^{32}$. 


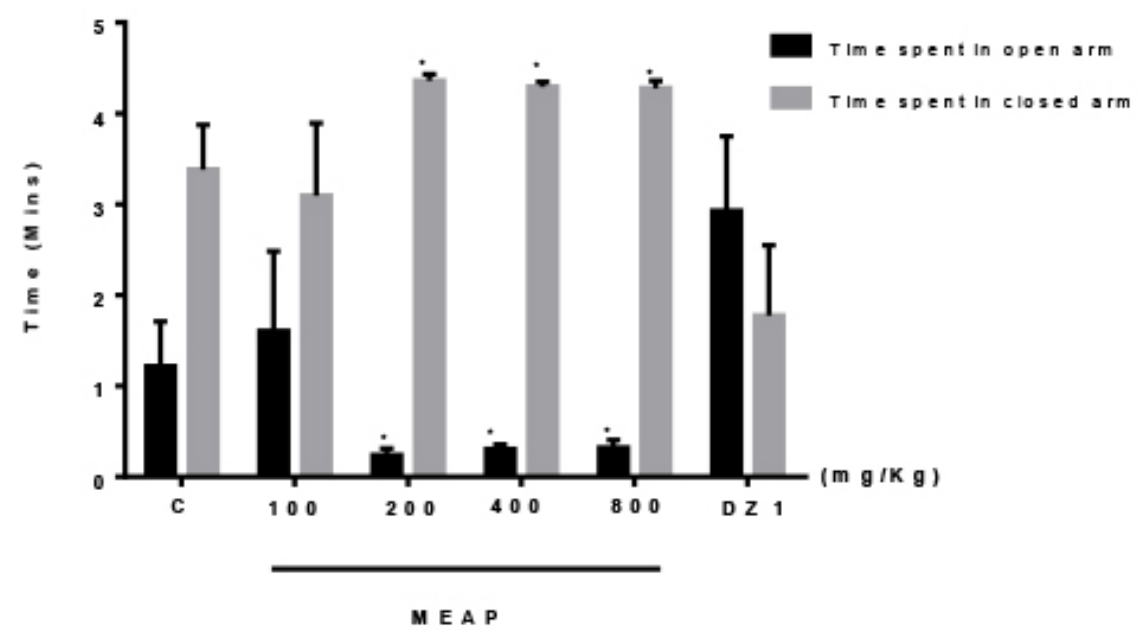

Figure 4: Effects of the methanol extract of the leaves of $A$. precatorius on the time spent in the open and closed arms respectively in the Elevated plus maze test in mice. Bars represent mean values with error bars. One-way ANOVA followed by Dunnet's multiple comparison test. ${ }^{*}<0.05$, indicate significant difference from the control (distilled water).

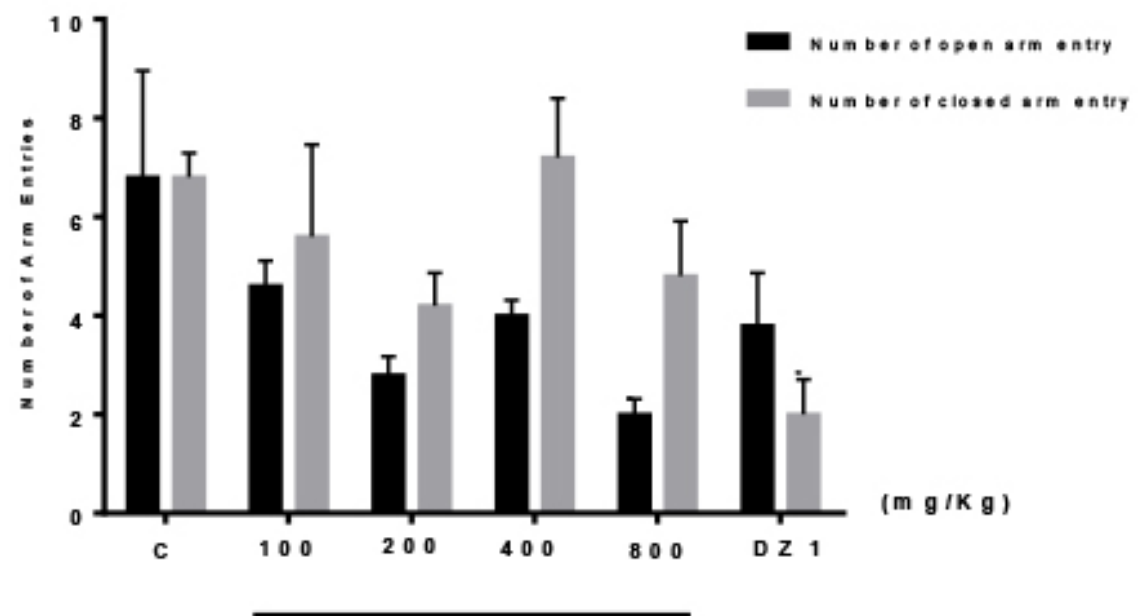

M E A P

Figure 5: Effects of the methanol extract of the leaves of $A$. precatorius on the number of open and closed arm entries in the elevated plus maze in mice Bars represent mean values with error bars. One-way ANOVA followed by Dunnet's multiple comparison test. * $p<0.05$, indicate significant difference from the control (distilled water) 


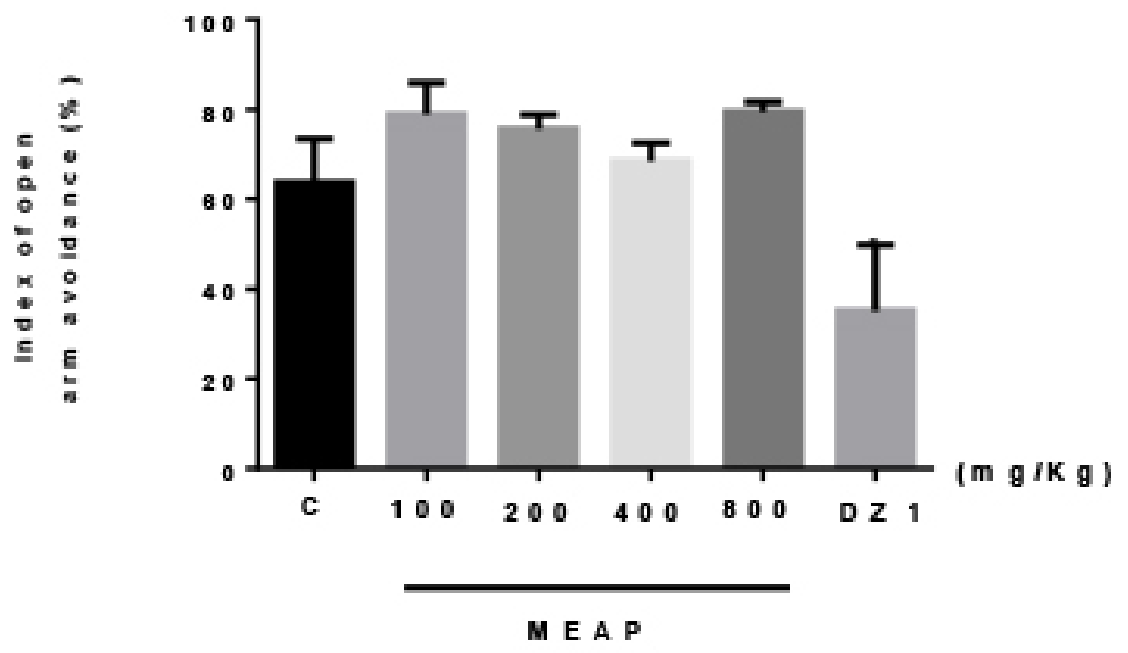

Figure 6: Effects of the methanol extract of $A$. precatorius leaves on the index of open arm avoidance Bars represent mean values with error bars. One-way ANOVA followed by Dunnet's multiple comparison test. ${ }^{*} p<0.05$, indicate significant difference from the control (distilled water).

Commonly,anti-seizure drugs are screened using PTZ-induced convulsion ${ }^{23,}{ }^{24}$. MEAP protected $25 \%$ at 400 and $800 \mathrm{mg} / \mathrm{kg}$ in PTZ-induced convulsion, but showed no protection in picrotoxin and strychnine-induced convulsion (Figure 8). Abolishment or increase in the seizure threshold is associated to anticonvulsant activity. This observation suggests that MEAP might possess anti-epileptic effect which is probably mediated by the chloride channel of GABA/benzodiazepine receptor complex and not by the chloride channel of glycine receptors. PTZ evokes convulsions via inhibition of GABAergic neurotransmissions by interfering with $\mathrm{GABA}_{\mathrm{A}}$ receptors ${ }^{25}$. The enhancement and inhibition of the neurotransmission of GABA will attenuate and enhance convulsion respectively ${ }^{26}$, ${ }^{27}$. Phenobarbitone and diazepam exert their antiepileptic effects by enhancing the GABA-mediated inhibition in the brain ${ }^{28}$. MEAP might possibly antagonize pentylenetetrazol convulsion by interfering with GABA aminergic mechanism(s) to exert its anticonvulsant effect. 


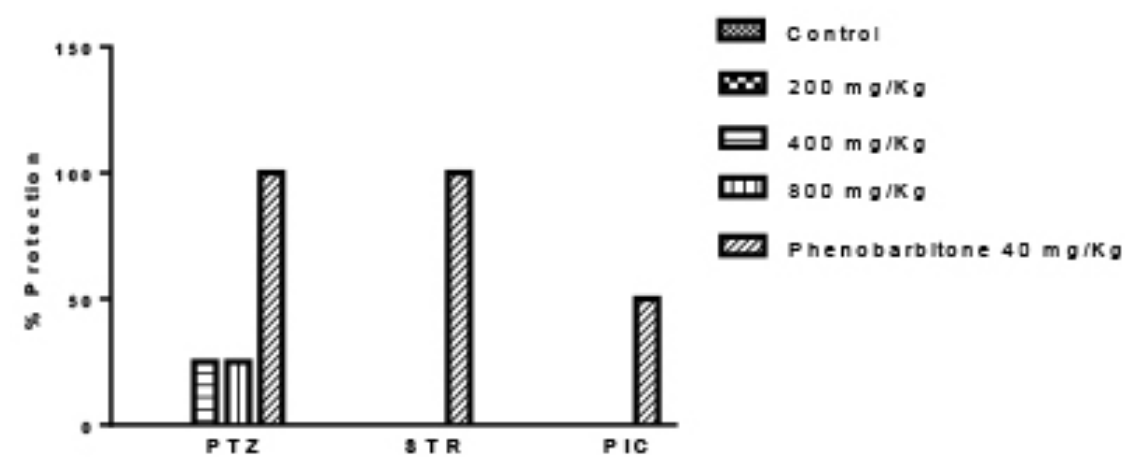

Figure 8: Effects of methanol extract of $A$. precatorius leaves on PTZ, Strychnine and Picrotoxin induced convulsions. Notes: PTZ Pentylenetetrazol 85mg/Kg; STR Strychnine $2 \mathrm{mg} /$ $\mathrm{Kg}$; PIC Picrotoxin $14 \mathrm{mg} / \mathrm{Kg}$

Increasing evidence from several studies indicates that antiepileptic drugs therapy may play a role in intellectual and behavioral impairment in children with epilepsy ${ }^{33}, 34$.

The findings of this study have shown that the methanol extract of Abrus precatorios has anticonvulsant and sedative actions ('activity' seems most suitable). These identified activities justify the proposition that the herbal (plant) extract should be subject to further experimental test conditions with human agents to properly determine how effective its use can be in the management of epilepsy. 


\section{REFERENCES}

1. Mattson, R. H.; Cramer, J. A.; Collins, J. F.; Department of Veterans Affairs Epilepsy Cooperative Study No. 264 Group*. A comparison of valproate with carbamazepine for the treatment of complex partial seizures and secondarily generalized tonic-clonic seizures in adults. NEJM.1992, 327, 765-771.

2. Brunton, P. J.; Sabatier, N.; Leng, G.; Russell, J. A. Suppressed oxytocin neuron responses to immune challenge in late pregnant rats: a role for endogenous opioids. EJN. 2006,23, 1241-1247.

3. Komolafe, M. A.; Sunmonu, T.A.; Fabusiwa, F.; Komolafe, E. O.; Afolabi, O.; Kett, M.; Groce, N. Women's perspectives on epilepsy and its sociocultural impact in south western Nigeria. AJNS. 2011, 30 .

4. Johannessen Landmark C.; Patsalos, P. N. Drug interactions involving the new second-and third-generation antiepileptic drugs. Expert Rev. Neurother.2010, 10, 119-40.

5. Kimiskidis, V. K.; Triantafyllou, N. I.; Kararizou, E.; Gatzonis, S. S.; Fountoulakis, K. N.; Siatouni, A.; Kaprinis, G. S. Depression and anxiety in epilepsy: the association with demographic and seizure-related variables. Ann. Gen. Psychiatry.2007,6, 28.

6. Bum, E. N.; Taïwe, G. S.; Moto, F. C. O.; Ngoupaye, G. T.; Nkantchoua, G. C. N.; Pelanken, M. M.; Rakotonirina, A. S.; Rakotonirina, A. Anticonvulsant, anxiolytic, and sedative properties of the roots of Nauclea latifolia Smith in mice. $E \& B . \mathbf{2 0 0 9}, 15,434-440$.

7. Ameen, O. M.; Olatunji, G. A.; Atata, R. F.; Usman, L. A. Antimicrobial activity, cytotoxic test and phytochemical screening of extracts of the stem of Fadogia agrestis.NISEB.2019, 11.

8. Ajayi, A. A.; Ukponmwan, O. E. Possible evidence of angiotensin II and endogenous opioid modulation of novelty-induced rearing in the rat. Afr. J. Med. Med. Sci.1994, 23, 287-290.

9. Hui, K. M.; Huen, M. S.; Wang, H. Y.; Zheng, H.; Sigel, E.; Baur, R.; Ren, H.; Li, Z. W.; Wong, J. T.; Xue, H. Anxiolytic effect of wogonin, a benzodiazepine receptor ligand isolated from Scutellaria baicalensis Georgi. Biochem. Pharmacol. 2002,64, 1415-1424.

10. Heo, H.; Shin, Y.; Cho, W.; Choi, Y.; Kim, H.; Kwon, Y. K. Memory improvement in ibotenic acid induced model rats by extracts of Scutellaria baicalensis. J. Ethnopharmacol. 2009,122, 20-27.

11. Brocco, M.; Dekeyne, A.; Veiga, S.; Girardon, S.; Millan, M. J. Induction of hyperlocomotion in mice exposed to a novel environment by inhibition of serotonin reuptake: a pharmacological characterization of diverse classes of antidepressant agents. Pharmacol. Biochem. Behav. 2002,71, 667-680.

12. Handley, S. L.; Mithani, S.; Effects of alpha-adrenoceptor agonists and antagonists in a mazeexploration model of 'fear'-motivated behaviour. N-S Arch Pharmacol. 1984, 327, 1-5.

13. Pellow, S.; Chopin, P.; File, S. E.; Briley, M. Validation of open: closed arm entries in an elevated plus-maze as a measure of anxiety in the rat. J Neurosci Methods. 1985, 14,149-167.

14. Lister, R. G. The use of a plus-maze to measure anxiety in the mouse. Psychopharmacol. 1987, 92,180-185.

15. Reddy, D. S.; Kulkarni, S. K. Differential anxiolytic effects of neurosteroids in the mirrored chamber behavior test in mice. Brain Res. 1997, 752, 61-71.

16. Swinyard, E. A.; Woodhead, J. H.; White, H. S.; Franklin, M. R. Antiepileptic drugs. by Levy, R. H., Dreyfuss, F. E., Mattson, R. M., Meldrum, B. S., Penry, J. K, Raven Press, New York. 1989:85.

17. Gupta, Y. K.; Malhotra, J.; George, B.; Kulkarni, S. K. Methods and considerations for experimental evaluation of antiepileptic drugs. IJPP. 1999, 43, 25-43. 
18. Briskin, D. P. Medicinal plants and phytomedicines. Linking plant biochemistry and physiology to human health. Plant Physiol.200o, 124, 507-514.

19. Wink, M. editor. Biochemistry of plant secondary metabolism. CRC Press; 1999.

20. Adedapo, A. A.; Abatan, M. O.; Olorunsogo, O. O. Effects of some plants of the spurge family on haematological and biochemical parameters in rats. Vet. Arh. 2007, 77, 29-38.

21. Ogbuehi, I. H.; Ebong, O. O.; Obianime, A. W. Oral acute toxicity (LD50) study of different solvent extracts of Abrus precatorius Linn leaves in wistar rats. Eur. J. Expt. Biol. 2015, 5, 18-25.

22. Meyer, B. N.; Ferrigni, N. R.; Putnam, J. E.; Jacobsen, L. B.; Nichols, D. J.; McLaughlin, J. L. Brine shrimp: a convenient general bioassay for active plant constituents. Planta Med.1982,45, 31-34.

23. Löscher, W.; Schmidt, D. Which animal models should be used in the search for new antiepileptic drugs? A proposal based on experimental and clinical considerations. Epilepsy Res.1988, 2, 145-181.

24. Okoye, T. C.; Akah, P. A.; Omeje, E. O.; Okoye, F. B.; Nworu, C. S. Anticonvulsant effect of kaurenoic acid isolated from the root bark of Annona senegalensis. Pharmacol.Biochem. Behav.2013, 109, 38-43.

25. Ramanjaneyulu, R.; Ticku, M. K. Interactions of pentamethylenetetrazole and tetrazole analogues with the picrotoxinin site of the benzodiazepine-GABA receptor-ionophore complex. Eur. J. Pharmacol. 1984, 98, 337-345.

26. Meldrum, B. GABA-agonists as anti-epileptic agents. Advances in biochemical psychopharmacology. 1981, 26:207.

27. Gale, K. GABA and epilepsy: basic concepts from preclinical research. Epilepsia. 1992, 33, S3-12.

28. Porter, R. J.; Meldrum, B. S. Antiseizure drugs. In Basic and clinical pharmacology, 11, pp.403-405.

29. Emamghoreishi, M.; Khasaki, M.; Aazam, M. F. Coriandrum sativum: evaluation of its anxiolytic effect in the elevated plus-maze. J. Ethnopharmacol.2005, 96, 365-370.

30. Mesfin, M.; Asres, K.; Shibeshi, W. Evaluation of anxiolytic activity of the essential oil of the aerial part of Foeniculum vulgare Miller in mice. BMC Complement. Altern. Med. 2014, 14, 310.

31. Hellion-Ibarrola, M. C.; Ibarrola, D. A.; Montalbetti, Y.; Kennedy, M. L.; Heinichen, O.; Campuzano, M.; Tortoriello, J.; Fernández, S.; Wasowski, C.; Marder, M.; De Lima, T. C. The anxiolytic-like effects of Aloysia polystachya (Griseb.) Moldenke (Verbenaceae) in mice. $J$. Ethnopharmacol. 2006, 105, 400-408.

32. Griebel, G.; Perrault, G.; Sanger, D. J. Characterization of the behavioral profile of the nonpeptide CRF receptor antagonist CP-154,526 in anxiety models in rodents Comparison with diazepam and buspirone. Psychopharmacol.1998, 138, 55-66.

33. Camfield, C. S.; Chaplin, S.; Doyle, A. B.; Shapiro, S. H.; Cummings, C.; Camfield, P. R. Side effects of phenobarbital in toddlers; behavioral and cognitive aspects. J. Pediatr. 1979, 95, 361365 .

34. Vining, E. P.; Mellits, E. D.; Dorsen, M. M.; Cataldo, M. F.; Quaskey, S. A.; Spielberg, S. P.; Freeman, J. M. Psychologic and behavioral effects of antiepileptic drugs in children: a doubleblind comparison between phenobarbital and valproic acid. Pediatrics.1987, 8o, 165-174. 